\title{
Denys-Drash syndrome, septated vagina and low level of anti-Mullerian hormone in male neonate
}

\author{
Hong Jun Lee, MD, \\ Jung-Sook Yeom, MD, \\ Ji Sook Park, MD, PhD, \\ Eun Sil Park, MD, PhD, \\ Ji-Hyun Seo, MD, PhD, \\ Jae Young Lim, MD, PhD, \\ Chan-Hoo Park, MD, PhD, \\ Hyang-Ok Woo, MD, PhD, \\ Hee-Shang Youn, MD, PhD \\ Department of Pediatrics, \\ Gyeongsang National University \\ School of Medicine, Jinju, Korea
}

\begin{abstract}
There is a wide variety of genital abnormalities observed in patients with DenysDrash syndrome (DDS). WT1 is thought to influence the genes related to genital development and mutations in this gene have been associated with DDS. DDS should be considered in the differential diagnosis of newborns with genital anomalies. In contrast to other conditions with $46, \mathrm{XY}$ disorders of sex development, individuals with DDS often have duplicated genital organs (a double vagina, cervix or uterus). A double uterus has not yet been reported with 1390G >A (Arg464 Asn) mutation. However, duplicated genitals have been reported with other genetic mutations in patients with DDS. The duplicated genitals in DDS may be associated with low anti-Mullerian hormone (AMH) secretion. Measurement of the AMH levels may add to our understanding of variations in genital development and their abnormalities in disorders such as DDS. In conclusion, this is first case of low level of AMH and double uterus in 1390G >A (Arg464 Asn) mutations of DDS male.
\end{abstract}

Keywords: Wilms tumor gene, Denys Drash Syndrome, Anti-Mullerian hormone

\section{Introduction}

Denys-Drash syndrome (DDS, ONIM number 194080) is a complex disorder characterized by nephropathy, Wilms tumor and 46,XY disorders of sex development (DSD) ${ }^{1,2)}$. The abnormalities identified in DDS have been attributed to mutations in the WT1 gene ${ }^{3-6)}$. The finding of 46,XY DSD, during the neonatal period, is suggestive of the diagnosis of DDS. AntiMullerian hormone (AMH), also known as Mullerian inhibiting substance (MIS), a member of the transforming growth factor of the transforming growth factor- $\beta$ superfamily produced by Sertoli cells of the fetal testis from 7 weeks gestation, is responsible for the regression of Mullerian ducts in male fetuses, the first step of male sex differentiation of the genital tract.

Because Wilms tumor 1 (WT1) gene product suppress AMH gene, mutations in WT1 can cause persistence of the Mullerian duct in men ${ }^{77}$. AMH begins to be expressed in a sexually dimorphic pattern during embryo development. In mice, AMH is expressed in male embryonic Sertoli cells from embryonic day 13 until birth ${ }^{8)}$.

Here, we report a neonate with double uterus of DDS and a low level AMH firstly checked in human patient with DDS.

\section{Case report}

A 2-day-old Korean newborn was referred to Gyeongsang National University Hospital with ambiguous genitalia (hypospadias without testis). The baby was born after 39 weeks of gestation and weighed 3,000 g. There were no perinatal problems. The external genitalia length of patient was $2.5 \mathrm{~cm}$ sized and urethral opening was placed at ventral side. Testis was not palpable with pigmented scrotum like structure (Fig. 1). On admission to our hospital, the blood pressure was $86 / 48 \mathrm{mmHg}$. The initial laboratory tests revealed; hemoglobin, $16.7 \mathrm{~g} /$ 
$\mathrm{dL}$, blood urea nitrogen, $15 \mathrm{mg} / \mathrm{dL}$, serum creatinine, $0.2 \mathrm{mg} /$ $\mathrm{dL}$, albumin, $3.4 \mathrm{~g} / \mathrm{dL}$, total cholesterol, $133 \mathrm{mg} / \mathrm{dL}$, and sodium, $146 \mathrm{mEq} / \mathrm{L}$. The urinalysis was normal. The echocardiogram showed no cardiac abnormality. The abdominal ultrasound and voiding cystography showed seminal ducts, bilateral testes in the inguinal areas and a double uterus located between the bladder and the rectum (Fig. 2). The karyotype was 46, XY. We analyzed WT1 the mutation in this patient after obtaining informed consent from the parents. The WT1 gene was evaluated after the extraction of genomic DNA from peripheral blood nucleated cells using a commercial kit (QIAamp DNA Blood Mini Kit, QIAGEN, Hilden, Germany). Exons 1, 47 and 10, with their bilateral flanking introns, were amplified individually from the genomic DNA by polymerase chain reaction (PCR). Exons 1-10, with their bilateral flanking introns, were amplified individually from the genomic DNA by PCR. The PCR products were sequenced directly. A heterozygous missense mutation, p.D464N $(=\mathrm{p}$. Asp464Asn), reported as p.Asp396Asn, was detected in exon 8 of the WT1 gene (Fig. 3).

The AMH level was $6.24 \mathrm{ng} / \mathrm{mL}$ (normal range, 375-625 ng/ $\mathrm{mL})^{9)}$.

After the diagnosis of DDS the patient was discharged and followed-up as an outpatient with conservative management. The renal function, growth and development remained normal at the last follow-up at 10 months of age.

\section{Discussion}

A recent study reported that the WT1 gene controls MIS expression by inhibiting AMH secretion. The WT1, SRY box protein 9 , and steroidogenic factor 1 could synergistically activate the MIS promoter, but without WT1, MIS promoter was not activated. The WT1 is an essential factor for activation of the MIS promoter; therefore, the persistence of the Mullerian duct in patients with DDS may result from deregulation of the MIS gene ${ }^{10)}$.

This is the first case study to measure the AMH levels in a patient with DDS. DDS is characterized by a wide variety of genital anomalies including 46,XY DSD. The external genitalia of patients can be female, male or ambiguous. In addition, the internal genitalia can vary and can include normal-sized testes in the normal position together with fully feminized genital organs (vagina, cervix, and uterus); however, there can also be abnormal-sized testes in abnormal positions together with
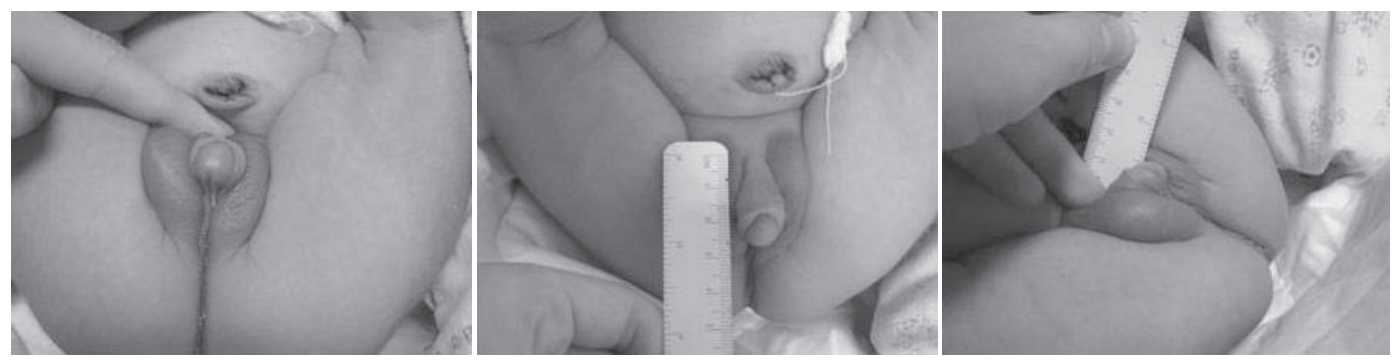

Fig. 1. The external genitalia was characterized by hypospadias and cryptorchidism.

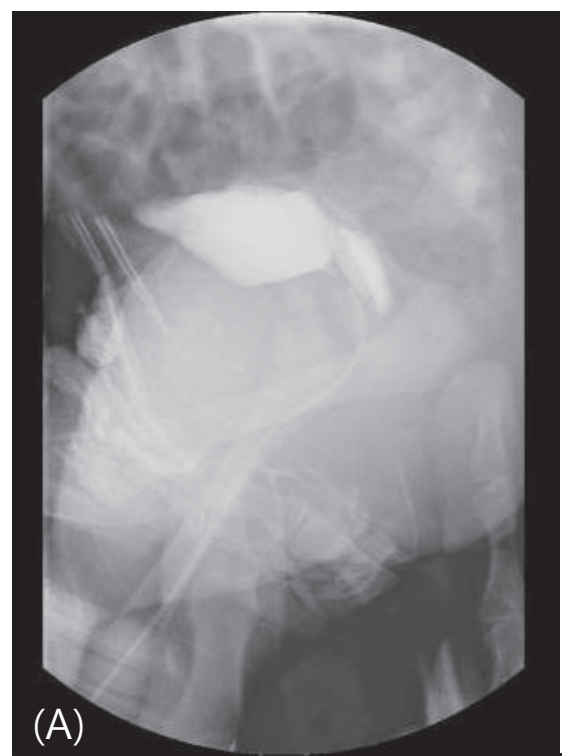

(B)

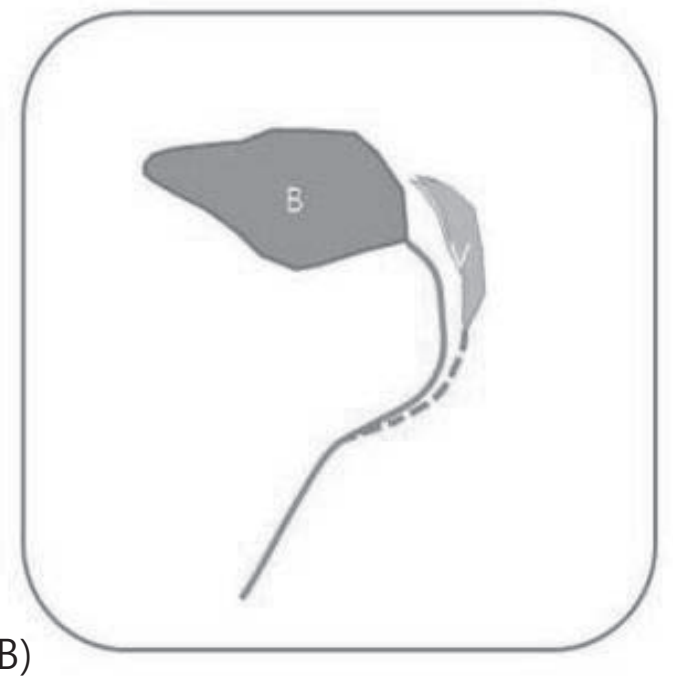

Fig. 2. Voiding cystography and simplified figure. (A) Voiding cystography showed double uterus. (B) Simplified figure of voiding cystography. B, bladder; V, vagina. 
WT1 NM_024426.3 reference sequence Patient's sequence

Patient's sequence WT1 NM 24426.3: c.1390G >A (p.Asp464Asn)

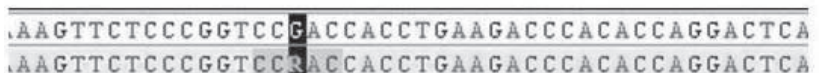

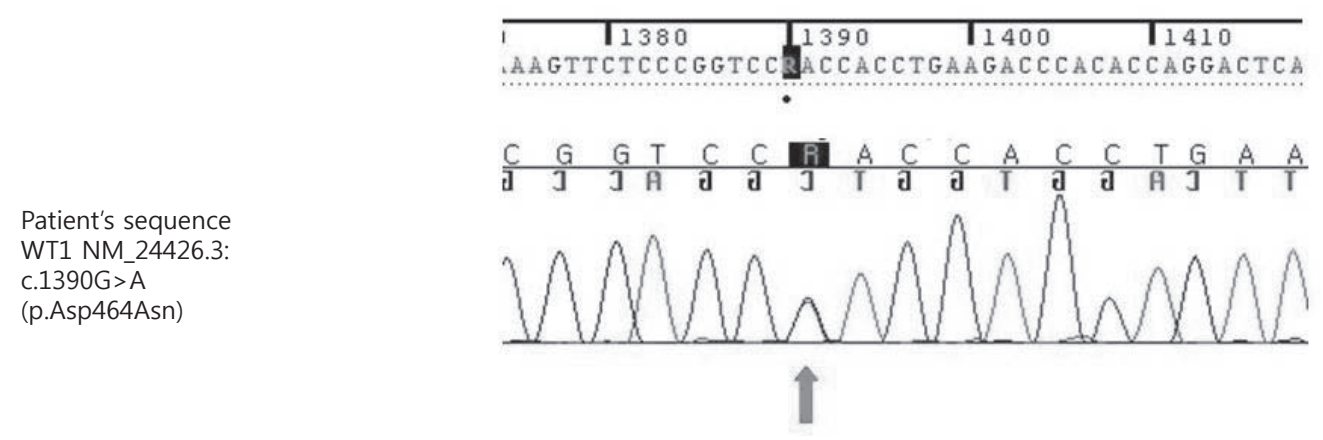

Fig. 3. Direct sequencing analyses of the WT1 gene. The patient had a known Asp464Asn missense mutation, which was reported as Asp396Asn mutation on the Human Gene Mutation Database.

Table 1. Overview of all D396N-WT1 gene mutations

\begin{tabular}{|c|c|c|c|c|}
\hline Reference & Diagnosis & Phenotype & Karyotype & Clinical features \\
\hline Pelletier et al. [1991] ${ }^{11)}$ & DDS & Female & $46, X Y$ & $\begin{array}{l}\text { Right gonad-dysgenic testis, left gonad-streak, no Mullarian structures, } \\
\text { no Wolffian structure, no Wilms' tumor, gonadoblastoma }\end{array}$ \\
\hline Baird et al. [1992] & DDS & Ambiguous & $46, X Y$ & Typical nephropathy, unilateral Wilms' tumor \\
\hline Little et al. [1993] $]^{13)}$ & DDS & Female & $46, X X$ & Nephropathy, bilateral Willms'tumor \\
\hline \multirow[t]{2}{*}{ Nordenskjold et al. [1994] ${ }^{14)}$} & DDS & Ambiguous & $46, X Y$ & $\begin{array}{l}\text { Hypospadias, cryptorchidism, bifid scrotum, nephropathy, bilateral } \\
\text { Wilms' tumor }\end{array}$ \\
\hline & DDS & Female & $46, X X$ & Nephropathy, unilateral Wilms' tumor \\
\hline Takata et al. [2000] ${ }^{16)}$ & DDS & Male & $46, X Y$ & Hypospadias, cryptorchidism \\
\hline
\end{tabular}

DDS, Denys-Drash syndrome.

various combinations of duplicated internal genital organs. The persistent Mullerian duct syndrome is in the differential diagnosis of ambiguous genitalia; these patients have male external genitalia, but do not have duplicated genitalia as in DDS.

It is unclear why duplicated genitalia are found in the DDS but not in the persistent Mullerian duct syndrome; both syndromes have been associated with low level of AMH. Previous study showed that the level of AMH in the persistent Mullerian duct syndrome is $0-10 \mathrm{pg} / \mathrm{mL}$, so low level of AMH can not discriminate these two clinical condition.

The mutation identified in this patient had been previously described with DDS ${ }^{11-14}$. However, this is the first case of DDS with a bicornate uterus (Table 1). DDS with duplicated internal genital organs has been reported with several different mutations ${ }^{15}$. However, duplicated internal genitals are not always present in patients with DDS.

Although many different WTI mutations have been identified with DDS, there is no clear genotype-phenotype correlation to date ${ }^{15)}$. However, our case suggests that measurements of AMH in patients with DDS might improve our understanding of the association between WT1 and the MIS gene and their role in genital development.

\section{Conflict of interest}

No potential conflict of interest relevant to this article was reported.

\section{References}

1. Denys P, Malvaux P, Van Den Berghe H, Tanghe W, Proesmans W. Association of an anatomo-pathological syndrome of male pseudohermaphroditism, Wilms' tumor, parenchymatous nephropathy and XX/XY mosaicism. Arch Fr Pediatr 1967;24:729-39.

2. Drash A, Sherman F, Hartmann WH, Blizzard RM. A syndrome of pseudohermaphroditism, Wilms' tumor, hypertension, and degenerative renal disease. J Pediatr 1970;76:585-93.

3. Armstrong JF, Pritchard-Jones K, Bickmore WA, Hastie ND, Bard JB. The expression of the Wilms' tumour gene, WT1, in the developing mammalian embryo. Mech Dev 1993;40:85-97.

4. Pritchard-Jones K, Fleming S, Davidson D, Bickmore W, Porteous D, Gosden C, et al. The candidate Wilms' tumour gene is involved in genitourinary development. Nature 1990;346:194-7. 
5. Kreidberg JA, Sariola H, Loring JM, Maeda M, Pelletier J, Housman D, et al. WT- 1 is required for early kidney development. Cell 1993;74:679-91.

6. Bruening W, Bardeesy N, Silverman BL, Cohn RA, Machin GA, Aronson AJ, et al. Germline intronic and exonic mutations in the Wilms' tumour gene (WT1) affecting urogenital development. Nat Genet 1992;1:144-8.

7. Shimamura R, Fraizer GC, Trapman J, Lau YfC, Saunders GF. The Wilms' tumor gene WT1 can regulate genes involved in sex determination and differentiation: SRY, Müllerian-inhibiting substance, and the androgen receptor. Clin Cancer Res 1997;3(12 Pt 2):2571-80.

8. Munsterberg A, Lovell-Badge R. Expression of the mouse anti-müllerian hormone gene suggests a role in both male and female sexual differentiation. Development 1991;113:613-24.

9. Belville C, Josso N, Picard JY. Persistence of Müllerian derivatives in males. Am J Med Genet 1999;89:218-23.

10. Hossain A, Saunders GF. Role of Wilms tumor 1 (WT1) in the transcriptional regulation of the Mullerian-inhibiting substance promoter. Biol Reprod 2003;69:1808-14.
11. Pelletier J, Bruening W, Kashtan CE, Mauer SM, Manivel JC, Striegel JE, et al. Germline mutations in the Wilms' tumor suppressor gene are associated with abnormal urogenital development in Denys-Drash syndrome. Cell 1991;67:43747.

12. Baird PN, Santos A, Groves N, Jadresic L, Cowell JK. Constitutional mutations in the WT1 gene in patients with Denys-Drash syndrome. Hum Mol Genet 1992;1:301-5.

13. Little MH, Williamson KA, Mannens M, Kelsey A, Gosden C, Hastie ND, et al. Evidence that WT1 mutations in DenysDrash syndrome patients may act in a dominant-negative fashion. Hum Mol Genet 1993;2:259-64.

14. Nordenskjold A, Fricke G, Anvret M. Absence of mutations in the WT1 gene in patients with XY gonadal dysgenesis. Hum Genet 1995;96:102-4.

15. Little M, Wells C. A clinical overview of WT1 gene mutations. Hum Mutat 1997;9:209-25.

16. Takata A, Kikuchi H, Fukuzawa R, Ito S, Honda M, Hata J. Constitutional WT1 correlate with clinical features in children with progressive nephropathy. J Med Genet 2000;37:698-701. 